\title{
In honor of a great inquirer: Curt Richter
}

\author{
JAY SCHULKIN \\ University of Pennsylvania, Philadelphia, Pennsylvania
}

An extraordinary American inquirer has recently passed away. His name was Curt Richter. He was born in 1894, in Denver, Colorado. His parents had arrived several years earlier as immigrants from Germany. He did his undergraduate work at Harvard, with an interest in engineering, and did his doctoral work in the laboratory of John Watson at Johns Hopkins University. Watsonian theorizing, however, seemed to have little or no impact on him. As a graduate student, Richter for the most part worked alone, as he did most of his life, and was selfeducated.

Paul Rozin (1976a) characterized Curt Richter as the "compleat psychobiologist" because of the way he went about addressing questions, the simple and straightforward answers he got, and the wide range of subject matter he studied. In fact, no one in this century in the field of psychobiology has made as many discoveries as has Richter.

Just entertain the scope of his investigations for a moment. They ranged from the study of spontaneous behavior, endocrine control of behavior, comparative analysis of behavior, taste psychophysics, nutritional requirements during reproduction, temperature regulation, and mechanisms of motor control to the origins of the use of fire, the biological contributors of manic depression, and the effects of voodoo on sudden death (see the collected works, Richter, 1976). Interestingly, Richter called hopeless the way in which an animal gives up after learning that it is unable to do anything about its condition. This phenomenon has come to be called learned helplessness (Seligman, 1975). His work on the biological clocks has proven fundamental in the analysis of behavior. The body is replete with endogenous clocks. He was also correct in thinking that the anterior hypothalamus, and what was later uncovered as the suprachiasmatic nucleus within the anterior hypothalamus, is responsible for the circadian rhythm controlling behavior (Richter, 1965; Rosenwasser $\&$ Adler, 1986). His work on poison avoidance (neophobia) was a precursor to the modern work on taste avoidance learning (Garcia \& Ervin, 1968).

Richter was very much at home in the physiological tradition of Claude Bernard $(1865,1957)$ and Walter Cannon $(1915 / 1929,1932 / 1965)$. Behavior was one way in which

\footnotetext{
The author wishes to thank his colleagues for their helpful suggestions. Correspondence may be sent to Jay Schulkin, Department of Anatomy, University of Pennsylvania, Philadelphia, PA 19104.
}

to maintain the constancy of the internal milieu. Experiments with rats in which he removed various endocrine glands and then demonstrated behavioral responses to correct the physiological imbalances are classic (see Richter, 1943, 1956). For example, he found that after loss of the parathroid gland, calcium is chronically lost; however, if given access to calcium, the rat can maintain its calcium requirements. He found similar effects in vitamindeprived rats. Behavioral responses to maintain the internal milieu took their most dramatic form in the self-selection experiments, in which he demonstrated that rats could maintain the constancy of various energy, mineral, and vitamin requirements when offered a choice of them in a purified form. The demonstration of behavioral homeostatic regulation is one of the hallmarks of the Richter legacy.

Closest to my line of work was Richter's demonstration of behavioral responses to tissue need for salt. After the removal of the adrenal gland, and therefore aldosterone, the sodium-retaining hormone of the adrenal gland, the animal chronically loses sodium. The result is fatal within 5 or 6 days. However, with access to sodium, the animal lives. It lives because it ingests salt. This is now well known (Epstein \& Stellar, 1955), but it wasn't in 1936, when Richter reported it. True to his German roots, Richter was a nativist and thought that the hunger for salt that results from sodium deficiency was innate. He was right about this (Denton, 1982; Wolf, 1969). He was probably too true to his German roots, however, in thinking that all of the hungers that he studied were innate, for they are not (Rozin, 1976b).

Curt Richter was no dust bowl empiricist. His empiricism, vast in scope (remarkably so), was not blind and without hypotheses. He was bold in his ideas and, amazingly, always simple. And what kept Richter's inquiries meaningful was his tie to biology. Unlike the mainstream of psychology, which in the middle part of the 20th century eschewed biological considerations, Richter's sanity was the fact that his thinking was always biological. His idea was that, if one wants to ask answerable questions, one should stay close to biology. Hence, his laboratory was called the "Psychobiology Laboratory."

Consider for a moment the place of Curt Richter in a larger cultural context. It is clear that he represents one of the best in the American tradition of inquirypragmatic, nonideological, biologically based, and always tied to invention. The tradition was started with Benjamin 
Franklin, the founder of the "American Philosophical Society: The Study of Practical Philosophy." Invention figured prominently in the thinking of Franklin. It figured no less in the thinking of Charles Saunders Peirce (1878), the inventor of pragmatism and William James's close colleague. And it figured no less for Richter, who understood that epistemological advances are dependent upon methodological innovations.

Inquiry is the big word in this tradition, and it is openended. Ingenuity of argument, or experimental control and elaborate statistical analysis, will not necessarily lead to truth. In fact, it often will not. Many good scholastic arguments or tightly controlled experiments still have no basis in reality and, therefore, are not to be believed. Neither rationalism nor British associationism, which came to dominate much of psychology, would do for Richter. Rather, the sense of being tied to nature was what was important to him. Most importantly, however, was his experimental sense of rolling up his sleeves and sniffing for what was relevant. He tended to be nativistic, but he always tested his ideas in rather simple and straightforward ways.

Curt Richter was working almost to the very end of his life. When his memory began to fail, he was busy reading books about memory and thinking of experiments. His spirit of inquiry was amazing. I had the good fortune to visit him at Johns Hopkins University a number of times over the last 10 years. He was always gracious and inviting, eager to learn about new discoveries in the field of psychobiology. At times, he would even muse about speculative issues in philosophy-if one of his guests had such an odd interest. Although he had no real students, all of us in this field are his students. The measure of his worth lies in the greatness of his empirical contributions and the spirit of inquiry with which he has left us.

\section{REFERENCES}

BERNARD, C. (1957). An introduction to the study of experimental medicine. New York: Dover. (Original work published 1865)

CANNON, W. B. (1929). Bodily changes in pain, hunger, fear and rage. New York: Harper Torchbooks. (Original work published 1915)

Cannon, W. B. (1967). The wisdom of the body. New York: Norton. (Original work published 1932)

DENTON, D. (1982). The hunger for salt. New York: Springer-Verlag.

Epstein, A. N., \& Stellar, E. (1955). The control of salt preference in the adrenalectomized rat. Journal of Comparative \& Physiological Psychology, 48, 167-172.

GarCIA, J., ERVIN, R. F. (1968). Gustatory-visceral and telereceptorcutaneous conditioning-adaptation to internal and external milieus. Communication in Behavioral Biology, 1, 389.415.

Perrce, C. S. (1878). How to make our ideas clear. Popular Science Monthly, 12, 287-302.

RICHTER, C. P. (1943). Total self regulatory functions in animals and human beings. Harvey Lecture Series, 38, 63-103.

RICHTER, C. P. (1956). Salt appetite of mammals: Its dependence on instinct and metabolism. In M. Auuori (Ed.), L'instinct dans le comportement des animaux et de l'homme (pp. 577-629). Paris: Masson et Cie.

RICHTER, C. P. (1965). Biological clocks in medicine and psychiatry. Springfield, IL: Charles C Thomas.

RICHTER, C. P. (1976). In E. M. Blass (Ed.), The psychobiology of Curt Richter. Baltimore: York Press.

Rosenwasser, A. M., AdLer, N. T. (1986). Structure and function in circadian timing systems: Evidence for multiple coupled circadian oscillators. Neuroscience \& Biobehavioral Reviews, 10, 431-448.

RozIN, P. (1976a). Curt Richter: The compleat psychobiologist. In E. M. Blass (Ed.), The psychobiology of Curt Richter (pp. xv-xxviii). Baltimore: York Press.

RozIN, P. (1976b). The selection of foods by rats, humans and other animals. In J. S. Rosenblatt, R. A. Hinde, E. Shaw, \& C. Beer (Eds.), Advances in the study of behavior (Vol. 6, pp. 21-76). New York: Academic Press.

Seligman, M. E. (1975). Helplessness. San Francisco: W. H. Freeman. WoLF, G. (1969). Innate mechanism for regulation of sodium intake. In C. Pfaffmann (Ed.), Olfaction and taste (pp. 548-553). New York: Rockefeller University Press.

(Manuscript received February 15, 1989.) 